\title{
The Spiritual Exercises and Illuminism in Spain: Dominican Critics of the Early Society of Jesus
}

\author{
Terence O'Reilly ${ }^{1}$ \\ University College Cork, Cork, Ireland \\ Terence.OReilly@ucc.ie
}

\begin{abstract}
The recovery of important historical texts in the last half century has provoked a reevaluation of the features of Ignatius of Loyola's Spiritual Exercises that have been described as "mystical" (especially their contemplative dimension and their implicit pneumatology), inviting us to reconsider the history of their composition and first reception, including the relationship between the spirituality of Ignatius to which they give expression, and the teachings of the illuminists or alumbrados. This article furthers this discussion by examining criticisms directed against the Spiritual Exercises during the last decade of Ignatius's life by two Spanish Dominicans, Melchor Cano and Tomás de Pedroche, who found parallels between the Exercises and the theology of the illuminists. These criticisms were serious enough to affect the received interpretation of what we now call the mystical aspects of the Exercises leading up to its codification in the Official Directory of 1599, particularly regarding the place, if any, of contemplation in the lives of the laity, the role of consolation in prayer, and the experience of direct divine guidance.
\end{abstract}

\section{Keywords}

Ignatius of Loyola - Melchor Cano - Tomás de Pedroche - Dominicans - Jesuits - The Spiritual Exercises - Illuminism - Erasmians

1 I am grateful to Joseph A. Munitiz, S.J., for his helpful comments on an earlier version of this study. 
The formation of a Jesuit culture after the death of Ignatius of Loyola (c.14911556) has become an object of growing interest in recent years, especially in the realms of art and architecture, music and science. ${ }^{2}$ Less attention has been paid to the history of Jesuit spirituality, even though, as Luce Giard has observed, it formed the "hard core" of Jesuit identity. ${ }^{3}$ This may be partly because to write about Jesuit spirituality in the early modern world is more difficult now than it was a generation ago, when Ignacio Iparraguirre, S.J. $(1911-73)^{4}$ completed his magisterial history of the Spiritual Exercises $[=S p . E x.] .{ }^{5}$ The perspective from which we view it has shifted, because of changes in how the $E x$ ercises are given and understood. At the pastoral level, there has been a return to the thirty-day individual retreat, and a new appreciation of the role of the person giving the Exercises (or the "director" as he/she was once called). In scholarship, a new theology of grace has made it possible to recover those elements of the Exercises that may be termed "mystical" or (better) "pneumatological," notably the fifteenth annotation [Sp.Ex. 15], the second time of election [Sp. Ex. 184-88], and consolation without preceding cause [Sp. Ex. 330]. This last development has been strengthened, in turn, by another: the study of the Exercises in the light of Ignatius's own interior life, as revealed above all in the Reminiscences and the Spiritual Diary. ${ }^{6}$

As a result of these changes, we have fresh questions to put to the historical evidence, particularly two. The first is one that Karl Rahner, S.J. (1904-84) ${ }^{7}$ raised forcefully: what parallels, if any, exist between the spirituality of the $E x$ ercises and the teachings of the Spanish illuminists or alumbrados, with whom

2 See, in particular, The Mercurian Project: Forming Jesuit Culture, 1573-1580, ed. Thomas M. McCoog, S.J. (Rome Institutum Historicum Societatis Iesu, 2004); The Jesuits: Cultures, Sciences and the Arts, 1540-1773, ed. John W. O'Malley, S.J., Gauvin Alexander Bailey, Steven J. Harris, and T. Frank Kennedy, S.J. (Toronto: Toronto University Press, 1999); The Jesuits and the Arts, 1540-1773, ed. John W. O'Malley, S.J., and Gauvin Alexander Bailey (Philadelphia: St. Joseph's University Press, 2005).

3 O'Malley et al., Jesuits: Cultures, 711.

4 See Diccionario Histórico de la Compañía de Jesús: Biográfico-temático [DHCJ], ed. Charles E. O'Neill and Joaquin María Dominguez, 4 vols. (Rome/Madrid: IHSI/Pontificia Universidad Comillas, 2001), 3:2062-63.

5 Ignacio Iparraguirre, S.J., Historia de los Ejercicios de San Ignacio, 3 vols. (Rome: Institutum Historicum Societatis Iesu, 1946-73).

6 Recent studies of the mysticism of Ignatius include Actualité de la mystique ignatienne (Paris: Médiasèvres, 2001); Philip Endean, S.J., "The Concept of Ignatian Mysticism: Beyond Rahner and de Guibert," The Way Supplement 103 (2002): 77-86; José García de Castro, S.J., "La mística de Ignacio: cultura y costumbre," Manresa 76 (2004): 333-53; Brian O'Leary, S.J., "The Mysticism of Ignatius Loyola," Review of Ignatian Spirituality 38.3, no. 16 (2007): 77-97; and Robert A. Maryks, ed., Companion to Jesuit Mysticism (Leiden: Brill, 2017).

7 DHCJ, 4:3279. 
Ignatius was associated by his detractors in both Spain and Italy? ${ }^{8}$ The second question is more general: in the decades after Ignatius's death, did the Society remain faithful to the "mystical" elements of the Exercises, or were there subtle alterations in how they were understood? ${ }^{9}$ Both questions are intriguing, indeed compelling. The fact is, however, that the present state of our knowledge does not permit us to answer either comprehensively. In order to tackle them, we require detailed scholarly reviews of the main episodes that occurred in the early history of the text and its reception. This article will consider one such episode, which took place during Ignatius's lifetime: the attack on the Exercises launched by certain Dominicans in Spain. It will consider the nature of their criticisms, including the parallels they drew between the theology of the Exercises and the teachings of the alumbrados, and it will conclude with some general comments on the long-term impact of their views.

In their response to the Exercises, the Dominicans of Ignatius's time were divided. Some esteemed and defended them as orthodox, notably Juan de la Peña $(c .1513-65)$ and Luis de Granada $(c .1504-88) .{ }^{10}$ Others criticized them for containing errors, superstitions, and features of a heretical kind. The leading critic was Melchor Cano (c.1509-6o), a professor of theology at Salamanca, who began to attack the Society and the Exercises in a series of sermons delivered in $1548 .{ }^{11} \mathrm{He}$ also committed his views to writing in the form of a short treatise, which circulated in manuscript during the 1550 os, both within his order and outside it. ${ }^{12}$ Equally hostile was the archbishop of Toledo of the time, Juan

8 Karl Rahner, "The Logic of Concrete Individual Knowledge in Ignatius Loyola," in The Dynamic Element in the Church, trans. W. J. O'Hara (London: Burns and Oates, 1964), 9394. See too William A. M. Peters, S.J., The Spiritual Exercises of St. Ignatius: Exposition and Interpretation (Jersey City: Program to Adapt the Spiritual Exercises, 1968), 2, 127, 183.

9 See Joseph Veale, S.J., “Dominant Orthodoxies," Milltown Studies 30 (1992): 43-65, reprinted in Manifold Gifts: Ignatian Essays on Spirituality (Oxford: Way Books, 2006) 127-49.

10 Eduardo Javier Alonso Romano, "Dominicos peninsulares amigos de los jesuitas," Archivo dominicano 26 (2005): 75-101, and 27 (2006): 117-42.

11 Antonio Astraín, S.J., Historia de la Compañía de Jesús en la asistencia de España, vol. 1: San Ignacio de Loyola, 1540-1556 (Madrid: Sucesores de Rivadeneyra, 1902), 321-40; Iparraguirre, Historia de los Ejercicios, 1:96-98; Feliciano Cereceda, S.J., Diego Laínez en la Europa religiosa de su tiempo, 1512-1565, 2 vols. (Madrid: Cultura Hispánica, 1945-46), 1:369-421; Cándido Pozo, S.J., "Cano, Melchor," in $D H C J, 1: 636-37$.

12 "Melchor Cano's Censura y parecer contra el Instituto de los Padres Jesuitas: A Transcription of the British Library manuscript," in Terence O'Reilly, From Ignatius Loyola to John of 
Martínez Guijeño (1486-1557), known as Silíceo, who, holding the Exercises in deep suspicion, set up a commission to investigate their orthodoxy in 1553. Its report was drawn up by the chairman, Tomás de Pedroche (d.1569), another Dominican. ${ }^{13}$

These two documents, the treatise of Cano and the report of Pedroche, are the main evidence we have for the Dominican case against the Exercises. In his study of them, Iparraguirre, like his predecessor Antonio Astrain, S.J. (18571928), ${ }^{14}$ is thorough and fair, but he is dismissive nonetheless. He sees much of their criticism as superficial and misinformed, and unduly shaped by the tempestuous personalities of the prime movers, Cano and Silíceo. ${ }^{15}$ It may be argued, however, that the arguments the documents advance are more cogent than he allowed. Both Cano and Pedroche focus on elements of the Exercises that we would now call mystical and make a case for the influence on them of illuminism. Their views, it should be said, are not always easy to interpret: they are expressed concisely, even elliptically at times, in a compact mixture of Spanish and Scholastic Latin. They become more comprehensible, however, when studied in the light of other writings by Cano himself and his fellow Dominicans in Spain.

\section{Melchor Cano}

For Melchor Cano, the Exercises of Ignatius were only one aspect of a larger series of problems connected with the reform movement in the Spanish church that came to the surface during the 1520 . Our main source for his ideas on this subject is the lengthy analysis of the catechism of Bartolomé Carranza (1503-76), his Dominican contemporary that he submitted to the Spanish Inquisition in $155^{8-59 .}{ }^{16}$ In this, he argued in detail that Carranza's theology was influenced by three currents of reform, all of them heterodox: Erasmianism, illuminism, and Lutheranism. Cano was not always precise in distinguishing these currents: for him, they were overlapping aspects of the same evil, the

the Cross: Spirituality and Literature in Sixteenth-Century Spain (Aldershot: Variorum, 1995), 1-22.

13 Tomás de Pedroche, O.P., Censura [...] contra los exercicios del P.M. Ignacio, in MHSI, Chronicon, 3:503-24.

$14 \quad D H C J, 1: 258$.

15 Iparraguirre, Práctica de los Ejercicios, 1:91 (Silíceo), 94 (Cano).

16 Qualificación hecha por los maestros Cano y Cuevas del Catechismo [y de otros escritos] 1558-1559, in Fray Bartolomé Carranza, Documentos históricos, ed. J. Ignacio Tellechea Idígoras, vol. 6 (Madrid: Real Academia de la Historia, 1981), 225-384. 
many-headed monster of heresy. Modern research, nevertheless, has confirmed certain aspects of his diagnosis. The reform movement in Spain was indeed composed of various strands, two of which were paramount. First, the Erasmians, whose following was strong in the court of Charles V (r.1519-56) and the University of Alcalá de Henares, where the Enchiridion of Erasmus (1466-1536) was published to popular acclaim in 1525. Second, the illuminists, who divided into two distinct and antagonistic groups: the recogidos, associated with the reformed Franciscans in Castile, and the dexados, whose center was the household of Diego López Pacheco (1456-1529), Marqués de Villena, in Escalona. ${ }^{17}$ Cano appears to have exaggerated the direct influence of Luther, though there is evidence that even in the 1520 s some of his writings were known in Castile. ${ }^{18}$ Between these various strands there were clearly many differences, but they shared a common cause in the renewal of the Spanish church, as Eugenio Asensio observed:

The territories of orthodoxy and heresy were hard to distinguish. All those pressing for a religious practice that was more intense, genuine and authentic seemed to be fellow-combatants in the same battle. Franciscan and Erasmian enthusiasms were not mutually exclusive. ${ }^{19}$

Cano believed that Ignatius was involved in the movement as an alumbrado, and Pedroche voiced the same opinion:

This Ignatius or Íñigo of Loyola, as is well known, was identified by the Inquisition as a heretic, one of the dexados and alumbrados. The said Íñigo or Ignatius fled away to Rome to escape from the Inquisition and the inquisitors. ${ }^{20}$

17 Marcel Bataillon, Érasme et l'Espagne, ed. Daniel Devoto and Charles Amiel, 3 vols. (Geneva: Droz, 1991), 1:179-242; 2:65-88; Joseph Pérez, "El erasmismo y las corrientes espirituales afines," in El erasmismo en España, ed. Manuel Revuelta Sañudo and Ciriaco Morón Arroyo (Santander: Sociedad Menéndez Pelayo, 1986), 323-28.

18 See the introduction to Jorge de Montemayor, Omelías sobre Miserere mei Deus, ed. Terence O'Reilly (Durham: University of Durham, 2000), 9-11.

19 "Los campos de ortodoxia y heterodoxia estaban mal deslindados. Todos cuantos defendían una religiosidad más intensa, más genuina y auténtica, parecían combatientes de la misma batalla. Fervores franciscanos y fervores erasmianos no se excluían." Eugenio Asensio, "El erasmismo y las corrientes espirituales afines," Revista de filología española 36 (1952): 31-99, here 73 .

20 "Este Ignacio o Iñigo de loyola, segun es fama fue notado en la Inquisicion por hereje. Uno de los dexados, y alumbrados, el cual Iñigo, o Ignacio, se fue huyendo a Roma para escaparse de la Inquisicion e Inquisidores." Pedroche, Censura, 504. 
On this point, it would seem, both were mistaken. Ignatius always protested that he was not an alumbrado, and there is no evidence that he was involved in either of the two wings or influenced by their ideas. Clearly, however, he was part of the general movement of reform in which they and the Erasmians were prominent. Many of his disciples and friends in Alcalá and Salamanca had Erasmian and illuminist contacts, including Manuel Miona (c.1477-1567), his confessor, and Miguel de Eguía (1495-1544), the printer of the Enchiridion, in whose home Ignatius stayed as a guest. ${ }^{21}$ There are also some striking similarities between the Spiritual Exercises and the teachings to which the reformers attached importance. It is these similarities that Cano and Pedroche note, especially three: the call to contemplation, the value of spiritual joy or consolation, and the experience of being guided by the Holy Spirit.

\section{Contemplation}

The movement of reform in Spain during the $15^{20}$ s was, in character, predominantly lay. This was true, above all, of the Erasmians, who took as their battle cry the theme of the Enchiridion, "monachatus non est pietas" (piety is not the preserve of the monk). ${ }^{22}$ They taught a spirituality for Christians living in the world in which the externals of Christian worship mattered less than the interior life, and to this end they encouraged a piety based not, primarily, on the liturgy or sacraments, but on Scripture and the imitation of Christ. ${ }^{23}$ Their enthusiasm for interiority and mental prayer was shared by both wings of the alumbrados, though with a difference: unlike the Erasmians, the illuminists drew inspiration, in different ways, from the monastic tradition, and its teachings on contemplation. This is apparent in the description of recogimiento presented by Francisco de Osuna (c.1497-1540) in his Tercer abecedario spiritual (Third spiritual primary), which was published in 1527 , when Ignatius was a student in Alcalá and Salamanca. ${ }^{24}$ By recogimiento Osuna appears to have

21 See Terence O'Reilly, "Erasmus, Ignatius Loyola and Orthodoxy," Journal of Theological Studies 30, no. 1 (1979): 115-27, here 118; Marcel Bataillon, Les jésuites dans l'Espagne du XVIe siècle, ed. Pierre-Antoine Fabre (Paris: Les Belles Lettres, 2009), 73-134, 147-49.

22 Bataillon, Érasme et l'Espagne, 1:220; 2:80-81.

23 See Erasmo: El Enquiridion o Manual del caballero cristiano, ed. Dámaso Alonso, with an introduction by Marcel Bataillon (Madrid: Consejo Superior de Investigaciones Científicas, 1971), 27-33; José Luis Abellán, El erasmismo español: Una historia de la otra España (Madrid: Gráficas Espejo, 1976), 74-76; Bernardo Monsegú, "Erasmo y Vives y la 'philosophia Christi' como humanismo cristiano," in El erasmismo en España, 357-72.

24 Francisco de Osuna, Tercer abecedario espiritual, ed. Saturnino López Santidrán (Madrid: Biblioteca de Autores Cristianos, 2005). 
meant both the disposing of the soul to experience contemplation and the incipient union with God that contemplation involves, and he was at pains to emphasize that it was accessible to all:

Since God does not have favorites, this communication is no less accessible to you (o man, whoever you may be) than it is to others, for you are made in the image of God no less than all others, and I do not think your desire to be blessed is less than theirs. ${ }^{25}$

Eleven years later, in 1538, Osuna's book introduced the young Teresa of Ávila $(1515-82)$ to mystical prayer. ${ }^{26}$

In their vocabulary and tone, the Exercises are neither Erasmian nor recogi$d o$, but they may be said to reflect similar concerns. Throughout his time in Spain, Ignatius was a layman; so too were his close companions, and most of the people to whom he offered guidance and instruction. This lay context is reflected in the Exercises themselves, which focus on the relationship between the individual and God, with few explicit references to the sacraments and the liturgy. ${ }^{27}$ To all who take them, they offer a training in mental prayer, and an interiorization of the Christian life, centred on the Gospels and the imitation of Christ. Although the word "contemplation" is not used in its monastic sense, the experience of God's presence, enflaming the soul in love, which the term normally denoted, is an integral part of the thirty-day retreat, as the fifteenth annotation, in particular, makes clear [Sp. Ex. 15]. Ignatius, however, nowhere distinguishes formally, as the monastic tradition did, between contemplation and action, no doubt because for him the two were intimately linked. Modern commentators on the Exercises have moved far from the debates of the early twentieth century between those who saw their purpose as a training of the will and others for whom their goal was contemplative union with God. The contrast, implicit in such views, between the ascetical and the mystical has

25 "Pues Dios no es aceptador de personas, esta comunicación no es a ti, o hombre, quienquiera que seas, menos posible que a los otros, pues que no eres menos hecho a imagen de Dios que todos los otros, ni creo que tienes menos deseo de ser bienaventurado que los otros." Osuna, Tercer abecedario espiritual, 95. On Osuna's teaching on prayer see Melquíades Andrés Martín, Los recogidos: Nueva visión de la mística española (1500-170o) (Madrid: Fundación Universitaria Española, 1975), 107-67.

26 "Osuna, Francisco de," in Diccionario de Santa Teresa de Jesús, ed. Tomás Álvarez (Burgos: Monte Carmelo, 2000), 1058.

27 See Karl Rahner, "Modern Piety and the Experience of Retreats," in Theological Investigations, trans. David Morland, O.S.B. (London: Darton, Longman and Todd, 1979), 16: $135-55$. 
been replaced by an approach in which both aspects are seen as "elements of the same relational reality."28 In the words of Tomáš Špidlík, S.J.:

Christian contemplation (theoría) is not the same as a false quietism. It is inseparable from action, from práxis [...]. The substance of one's contemplation should be powerful enough to be realised, incarnated, in the various circumstances of life. Rightly, therefore, in the Exercises choices are made, decisions and resolutions formed, to alter one's life. ${ }^{29}$

Cano's reservations about the lay and contemplative aspects of the Spanish reform may be seen in his comments on the catechism of Carranza. Two of them stand out. First, he believed it was a mistake to encourage everyone to aspire to contemplation. It was not a gift suitable to all, and it was incompatible, in principle, with the active life. The alumbrados, he noted, had praised and sought it, and in doing so they had neglected the virtues proper to living in the world. ${ }^{30}$ Second, he considered it pernicious to identify the practice of mental prayer with Christian perfection, because this would undermine the distinction between the lay vocation and the religious life. Perfection, he emphasized, involves literal poverty, chastity and obedience, in deference to the command of Christ, who did not say to his followers, "Go and pray mentally," but "Go, sell your possessions, and give the money to the poor" (Matthew 19:21):

And so the person who with no vow of chastity, but instead in the married state, with no vow of obedience, but instead in freedom, with no vow of poverty, but instead in wealth, simply with preparation of the soul, finds a standard path to Christian perfection, is a wrecker of the religious orders, a deceiver of the laity, and, indeed, blasphemes against the wisdom of Christ. ${ }^{31}$

28 Sylvie Robert, Union with God in the Ignatian Election, The Way Supplement 103 (Oxford, Way Publications, 2002), 111.

29 "La contemplazione (theoría) cristiana non si identifica con un falso quietismo. Essa è inseparabile dall'azione, dalla práxis [...]. Il pensiero contemplato deve avere la forza di realizzarsi, incarnarsi nelle diversi circostanze della vita. Giustamente, quindi, negli Esercizi si fanno le scelte, si prendono le decisioni, i propositi per cambiare vita." Tomáš Špidlík, S.J., Ignazio di Loyola e la spiritualità orientale: Guida alla lettura degli Esercizi (Rome: Studium, 1994), 118.

3o Cano, Qualificación [...] del Catechismo, 293-95.

31 "E así el que sin vocto de castidad, antes con estado de matrimonio; sin vocto de obediençia, antes con libertad; sin vocto de pobreza, antes con riquezas, solamente con preparaçión de el ánimo, halla camino hordinario para la perfectión christiana, es 
Parallel, though not identical views may be found in the writings of two of Cano's Dominican contemporaries, Juan de la Cruz (1542-91) (not to be confused with his Carmelite namesake) and Domingo de Soto (1494-1560). In 1556, the year of Ignatius's death, de la Cruz published an important study, the Diálogo de la oración vocal (Dialogue on vocal prayer), in which the burning issues of spirituality at the time are discussed by three fictional characters, all of them religious: Tomás and Antonio, who are Dominicans, and Bernardo, who belongs to another order, not named. ${ }^{32}$ Bernardo is an enthusiast for the ideals of the Spanish movement of reform, about which his friends, however, express reservations. At one point the discussion turns on the sort of people who should make contemplation their goal. Tomás expresses the conviction that it is mistaken to urge it on people who are inconstant in virtue or unsuited by their temperament to solitude and recollection. In his opinion, most of their contemporaries fall into the first category. He does not believe, however, that those suited are usually religious, and those unsuited lay: all should aspire to contemplation, whether married or not, though celibates have a greater opportunity, and more time, to do so. ${ }^{33}$ Domingo de Soto's views on the matter are similar. In his vernacular treatise on the love of God, he states that, in time given to prayer, all members of the church should strive after contemplation, but he distinguishes, more firmly than de la Cruz, between the religious and secular states. The time laity should give to prayer is severely limited by the responsibilities they have to others. One Mass each day, he writes, is sufficient for most lay people, and the extra time devoted to prayer should be mostly on feast days. At all other times they should attend to the active life, running their homes and practicing works of mercy. ${ }^{34}$

The development before $155^{\circ}$ of a lay spirituality, and of writings associated with it, appears to have caused in the older orders a crisis of confidence. At another point in the Diálogo of de la Cruz, Bernardo points out that many lay people excel religious in the depth of their spiritual lives, and that a large number of religious, who should be examples to the laity because of their calling, stand out only in liturgical prayer, which often lacks a spirit of devotion. On what grounds, then, he asks, can religious exalt their state above the lay? To this question he receives an unequivocal answer from Antonio, who explains

destruidor de las religiones, es engañador de el pueblo, e aun blasphemia de la sabiduria de Christo." Cano, Qualificación [...] del Catechismo, 295.

32 Juan de la Cruz, O.P., Diálogo sobre la necesidad de la oración vocal, in Tratados espirituales, ed. Vicente Beltrán de Heredia, O.P. (Madrid: Biblioteca de Autores Cristianos, 1962). On this work see Bataillon, Érasme et l'Espagne, 1:642-48; 2:228-30.

33 De la Cruz, Diálogo sobre la necesidad, 338-42, 367.

34 Soto, Tratado del amor de Dios, 164. 
that the religious state is not of greater perfection because of the mental prayer or contemplation of its members, but because of the virtues of poverty, chastity, and obedience which it professes, and which are solemnized by the three vows. $^{35}$

Such remarks can help us to comprehend two of the criticisms directed against the Exercises by Cano and Pedroche. First, both point out that people have different temperaments and needs, which the Exercises do not take into account. Cano writes of the Society: "These [people] provide everyone with the same exercises in contemplation, even though not everyone is suited for it." ${ }^{36}$ Here, the word contemplación appears to be used with its traditional monastic connotations. For Cano the Exercises were dangerous because they ignored the distinction between monastic and lay spirituality. In a letter of 1557 to a friend, fray Juan de la Regla (1500-74), he described the result: an undermining of the vocations of the lay people taking them:

If the cobbler, on making the Exercises, were to sew the shoe less efficiently, and if the cook were to prepare the stew badly, we would find it insufferable, however much it was claimed that they were given to devotion and meditation. And for this reason I have always believed that true Christianity and its Exercises make each person better in their calling. And one of the things that make me unhappy about these Theatine Fathers [i.e. Jesuits] is that the gentlemen whose direction they assume, instead of being turned into lions are made into hens, and if they are hens already, into chickens.

In this respect, he concluded, the Jesuits were illuminists: "These are the alumbrados that the Devil has sown so often in the Church."37

De la Cruz, Diálogo sobre la necesidad, 265-66, 281.

"Éstos tienen para todos unos mismos exercicios de contemplación, como no todos sean aptos para ella." Cano, Censura, 20.

"Si el zapatero, haciendo Exercicios, cosiese peor el zapato, y el cozinero guissare mal la olla, no lo podriamos sufrir, por mas que nos alegasse que se da a devocion y meditacion. Y assi siempre he creido que la verdadera christiandad y Exercicios de ella a cada cual mejoran en su oficio. Y una de las cosas que me mueven a estar descontento de estos Padres Teatinos es que los caballeros que toman entre manos, en lugar de hacerlos leones los hacen gallinas, y si los hallan gallinas los hacen pollos." And later, "éstos son los Alumbrados que el Demonio tantas veces ha sembrado en la Iglesia." The letter is edited in Fermín Caballero, Vida del Illmo. Melchor Cano (Madrid: Colegio Nacional de Sordomudos, 1871), 526. A similar objection to the Exercises was voiced by the Augustinian, Thomas of Villanueva (1488-1555), in a conversation which the Jesuit Antonio Araoz, reported to Ignatius in January 1546: see Iparraguirre, Práctica de los Ejercicios, 1:116. 
Second, both are appalled by Ignatius's insistence, in annotations fourteen and fifteen, that during the retreat the giver of the Exercises should refrain from actively encouraging the receiver to take religious vows [Sp. Ex. 14; 15]. In his copy of the text, Cano wrote beside annotation fourteen, "most pestilent rule," ${ }^{38}$ while Pedroche attacks annotation fifteen for not allowing the director to explain the teaching of the church on the pre-eminence of the religious life: "Certainly, it is astonishing that the preaching and persuading that are licit and holy when the exercises are not taking place should be illicit and forbidden during them and while they last." ${ }^{39}$

A second feature of the Spanish movement of reform the Exercises reflect is a ready acceptance of the value of spiritual joy. The Erasmians and the illuminists set great store by this, and, in doing so, criticized the piety of their day, which they considered wearisome and sorrowful to excess. In the Enchiridion, Erasmus repeatedly draws a contrast, in Pauline fashion, between the tedious devotions of those who identify prayer with ritual, and the joy of those who live in accord with the spirit of Christ, who told his disciples, "My yoke is easy, and my burden light" (Matthew 11:30). The alumbrados, similarly, deplored the negativity of much popular piety. The dexados preferred, instead, to celebrate with gratitude the benefits, or gifts, received from God, while the recogidos taught that consolation in prayer was a precious and normal part of the Christian life, inseparable from the experience of recogimiento itself. ${ }^{40}$ In the Tercer abecedario espiritual, Osuna describes it as one of the principal means by which virtue is strengthened and a person grows in intimacy with God:

Let us therefore seek the Lord along with his consolation, as do those who are just, and let us not separate him from his sweetness, even if the devil urges us to do so; instead, just as we believe him to be God and man,

38 "pestilentissima regula." Astraín, Historia de la Compañía de Jesús, 37on3. The Dominican theologian Mancio de Corpore Christi (1507-76), who was well disposed towards the Society, also had reservations about annotation fourteen, in which he discerned "doctrina iluminística": see Iparraguirre, Práctica de los Ejercicios, 1:117.

39 "Ciertamente es negocio de admiracion que la predicacion, y suasion que es licita, y sancta fuera del tiempo de los exercicios, no sea licita, ni se permita durando, y correndo el tiempo dellos." Pedroche, Censura, 509-10.

40 O'Reilly, "St. Ignatius Loyola and Spanish Erasmianism," Archivum historicum Societatis Iesu 43 (1974): 301. 
so let us seek him as both God and sweet; for just as the humanity [of Christ] is a pathway to God, so is his sweetness an incitement and a spur for us to run to him. ${ }^{41}$

He criticizes most severely those who, to dissuade others from desiring it, emphasize the dangers of self-love to which consolación may give rise. He argues, instead, that it may be desired and sought, and that the devil's main concern is to prevent its acquisition. It is, he affirms, connected closely with contemplation: "We must thank and bless the Lord [for] the contemplation we practise; in which the Lord communicates his grace and consolation more abundantly than in any other exercise." 42

Consolation has a central place, too, in the Spiritual Exercises, where the word itself, consolación, and its cognate, consolar, occur forty times. ${ }^{43}$ It is associated throughout with the action of God, who inspires in the soul a love, intensely felt, into which all other loves are gathered, disposing it to serve him henceforth in the best possible way. ${ }^{44}$ Its significance is underlined in the sixth annotation, where Ignatius warns that if the retreatant does not feel consolation, or its opposite, desolation, he or she may not be practising the exercises properly [Sp.Ex.6]. Commentators nowadays acknowledge its crucial role and pay due attention to the definition Ignatius provides of "consolation without preceding cause," a concept which previous writers tended to classify as "a limit case, virtually without practical relevance," but which is now considered an integral part of his theology.45

41 "Busquemos, pues, al Señor junto con su consolación, como lo buscan los justos, y no lo dividamos de su dulcedumbre, aunque el demonio nos lo amoneste; sino que así como lo creemos Dios y hombre, así lo busquemos Dios y dulce juntamente; porque así como la humanidad es vía para ir a Dios, así la dulcedumbre suya es un incitamiento y espuelas para que corramos a él." Osuna, Tercer abecedario espiritual, 347.

42 "Debemos hacer gracias y bendecir al Señor [por] la contemplación en que nos exercitamos; en la cual comunica el Señor su gracia y consolación con más abundancia que en otro ejercicio alguno." Osuna, Tercer abecedario espiritual, 134.

43 s.v. consolación, consolar, in Concordancia ignaciana: An Ignatian Concordance, ed. Ignacio Echarte, S.J. (Bilbao / Sal Terrae: Mensajero / Maliaño, 1996), 228-30.

44 Michael Ivens, S.J., Understanding the Spiritual Exercises, Text and Commentary: A Handbookfor Retreat Directors (Leominster/ New Malden: Gracewing / Inigo Enterprises, 1998), 14, 229.

45 Ivens, Understanding the Spiritual Exercises, 229. See José García de Castro Valdés, S.J., El Dios emergente: Sobre la "consolación sin causa" [EE 330] (Bilbao: Mensajero / Sal Terrae: Maliaño, 2001), and the same author's article, "Consolación sin causa precedente," in Diccionario de espiritualidad ignaciana, ed. José García de Castro et al., 2 vols. (Bilbao / Sal Terrae: Mensajero / Maliaño, 2007), 1:424-28. 
The value accorded to spiritual joy in the Spanish reform was noted by Melchor Cano in his commentary on Carranza's catechism. There, he argues that it is harmful to tell lay people that experience shows prayer to be restful and joyful. It may lead them to neglect good works, and, since their duty is to practise the active life, it would be much more helpful to laud works of charity. After reading such praise of prayer, he writes, the lazy (holgazanes) will turn to it out of sloth and for comfort and become enemies of work and the cross of Christ. Virtue, he concedes, may be a joyful experience for those who are perfect, but one should teach the ordinary layperson that it is difficult, and that the road to Paradise is narrow. ${ }^{46}$

His approach in this matter is echoed in the Diálogo of de la Cruz. Bernardo, the religious favorable to the movement of reform, praises consolation in terms reminiscent of Osuna: it encourages growth in the love of God and scorn of worldly contentment; it helps one to fulfil the commandments and virtues with greater ease; and it brings the spirit to life. He begs his Dominican listeners not to undervalue it. Neither of them, however, shares his views. Tomás replies at length, pointing out, first, that consolation is not related necessarily to the holiness of the person experiencing it. God often gives it to beginners, he says, to spur them on; he may well deny it to those more advanced, wishing to form within them a strong will. Indeed, it is sometimes granted to people who have not really begun to love him. It is a children's toy (regalo de niños), and one should not pray with a desire for it. ${ }^{47}$

Closely related is his second point: it is not, he affirms, an integral part of the spiritual life. To praise its effects is to forget that they do not proceed from the delight found in prayer, but from grace, and a determination to carry out the commandments. True devotion, in fact, may be found in those who do not experience spiritual joy, for devotion is not a synonym of consolation but a prompt and resolute will: "A prompt and resolute will by which man offers and surrenders himself to God."48

In the context of such arguments, it becomes easier to make sense of Cano's criticism that the Exercises claim, misleadingly, to impart an affective and joyful experience of divine love. People taking them, he indicates, are given to believe that they will experience the work of grace in the soul, tenderness of heart, and feelings of a spiritual kind. This is "unhealthy," a presumptuous attempt to force God's hand:

46 Cano, Qualificación [...] del Catechismo, 355-56.

47 De la Cruz, Diálogo sobre la necesidad, 290-92.

48 "una pronta y determinada voluntad con que el hombre se ofrece y entrega a Dios." De la Cruz, Diálogo sobre la necesidad, 292-93. 
To this should be added the fact that among the same exercises there are some that are not so wholesome, for at the end of so many weeks are promised grace, and tenderness of heart and spiritual feelings: this seems to place God under an obligation, which is one way of tempting him. ${ }^{49}$

He pours scorn, too, on the tendency of Ignatius's followers to speak readily about the spiritual feelings they have received, and to celebrate God's love: "After four days they immediately go around putting into words their feelings and tender sentiments, and beginning their talks and conversations with, 'And how good God is, and how lovable!"'50

In this he discerns the work of the devil, who disguises himself as an angel of light (cf. 2 Corinthians 11:14), and the spirit of the alumbrados, whom he deceived:

The sight of certain people bearing great spiritual fruit among the Christian populace does not prove or demonstrate that this is not a trick of the devil, for when, being a diligent deceiver of those who are good, he cannot succeed under the guise of evil, he sometimes turns himself into an angel of light, and gives enlightenment and spiritual feelings, and in this way he even helps many along the path to heaven, but only to later lead many others along the path, and into the pit of hell; and of this we have in Spain a clear example in the Alumbrados and Dexados. ${ }^{51}$

Pedroche's view of Ignatian consolation is sceptical too. He quotes part of the definition of it presented in the first set of rules for discerning spirits, ${ }^{52}$ where it is associated with an interior motion of love so intense that all created things

49 "Añádese a esto que con los mismos exercicios hay algunos no tan sanos, porque post tot septimanas pollicentur gratiam y ternura de corazón y sentimientos espirituales, que parece obligar a Dios, que es un género de tentarle." Cano, Censura, 20.

5o "A cabo de quatro días andan luego diciendo sus sentimientos y ternuras, y comenzando sus pláticas y hablas por ‘¡Y quán bueno es Dios, y quán amable!” Cano, Censura, 22.

$5^{1}$ "El ver que una gente haga mucho provecho espiritual en el pueblo Christiano no convence ni concluye no ser artificio del demonio, pues como solícito engañador de los buenos, ya que no puede por especie de mal, se transfigura algunas veces en ángel de luz, y alumbra y da sentimientos espirituales, y aun ayuda de esta suerte a muchos en el camino del cielo para después dar con otros muchos en el camino y hoyo del infierno, como tenemos exemplo manifiesto en España de los Alumbrados y Dexados." Cano, Censura, 12.

$5^{2}$ Pedroche, Censura, 520: "Spiritualis proprie consolatio tunc esse noscitur quando per internam quamdam motionem exardescit anima in amorem Creatoris sui." The passage quoted is from Exx. 316 in the versio vulgata translation of the Exercises, reproduced in MHSI, Exerc. Spir., 376. 
are loved in God alone, and he asks if a person can ever be sure that joy experienced in prayer has a spiritual cause. His emphatic answer is no:

Without a doubt this is nothing other than recognizing what is unknown by what is even more unknown, for that interior motion, and that state in which man can no longer love any creature except for the sake of God, are much more unknown to man than spiritual consolation itself. ${ }^{53}$

\section{$5 \quad$ The Holy Spirit}

A third feature of the Spanish movement of reform that may be found in the Exercises concerns the Holy Spirit: the belief that a Christian may expect divine guidance in every aspect of life and should prepare to receive it by allowing God to act in the soul. Among the tenets of the dexados that the Inquisition condemned in 1525 there is the following remark: "That the love of God in man is God, and that they should surrender themselves to this love of God, which orders people in such a way that they cannot commit sins, either mortal or venial." 54

Scholars have interpreted these words in various ways, but for the inquisitors their meaning was straightforward: abandoning oneself to God's love gave one freedom to sin..$^{55}$ Dexamiento was defined in similar terms by John of Ávila (1499-1569), Ignatius's contemporary and friend. In his Audi, filia (Listen, daughter), published in 1556 , he mentions certain people who believed that once abandoned perfectly to God's love they could not sin, and that every impulse they experienced came from the Spirit, even if it meant breaking the commandments, or neglecting to do a good work:

It seemed to them that on giving themselves perfectly to him, and leaving themselves in his hands, they were so loved by God, and ruled by the Holy

53 "Procul dubio nihil aliud hoc est quam ignotum cognoscere per ignotius quando quidem illa interna motio, et ille status in quo homo iam non potest creaturam ullam nisi propter Deum diligere, multo magis ignotum est homini quam spiritualis consolation." Pedroche, Censura, 520 .

54 "Que el amor de dios en el hombre es dios y que se dexassen a este amor de dios que ordena las personas de tal manera que no pueden peccar mortal ni venialmente." Edicto de los alumbrados de Toledo (23 de septiembre de 1525), proposition 9, in Antonio Márquez, Los alumbrados: orígenes y filosofía, 1525-1559 (Madrid: Taurus, 1972) 276.

55 See Alistair Hamilton, Heresy and Mysticism in Sixteenth-Century Spain: The Alumbrados (Cambridge: James Clarke, 1992), 34-36. 
Spirit, that everything that came into their heart was nothing other than a light and an instinct from God. ${ }^{56}$

To combat this doctrine, Ávila cites Galatians 5:18: "If you are led by the Spirit you are not under the law." The Holy Spirit, he explains, fills the soul with a love of God that spurs it to do his will perfectly, and to such an extent that if the law were suddenly lost it would be found inscribed in the will of the soul. Liberty in this context means freedom from sadness and fear:

The person who possesses in abundance this Spirit of God, who confers freedom, is so exempt in his actions from heaviness and constraint that even if there were no hell to threaten him, no paradise to attract him, and no commandment to restrain him, he would act as he does, solely out of love for God. ${ }^{57}$

Ávila does not refer to the Exercises here, and there is no reason to suppose that he had them in mind. His words throw light, nonetheless, on the connection the Exercises imply between an increasingly selfless love of God that the Four Weeks encourage, and sensitivity to the promptings of grace, which the retreatant gradually acquires. ${ }^{58}$ The other wing of the illuminists, the recogidos, did not teach abandonment in the way the dexados appear to have understood it, but they too fostered openness to the inspiration and operations of God. In the influential Via spiritus of Bernabé de Palma (1469-1532), published in 1532,

$5^{6} \quad$ "Parecíales que, dándose una vez perfectamente a El, y dejándose en sus manos, eran tanto amados de Dios, y regidos por el Espíritu Santo, que todo lo que a su corazón venía no era otra cosa sino lumbre e instinto de Dios." Audi, filia (edition of Alcalá de Henares, 1556), in Obras completas del santo maestro Juan de Ávila, ed. Luis Sala Balust, rev. Francisco Martín Hernández, 6 vols. (Madrid: Biblioteca de Autores Cristianos, 1970), 1:496. See José María Lera, S.J., "La contemplación para alcanzar amor, el pentecostés ignaciano: apuntes para una pneumatología de los Ejercicios (111)," Manresa 63 (1991): 163-9o, here 179 .

57 "Quien aqueste Espíritu de Dios, que hace libre, tiene en abundancia, obra tan sin pesadumbre y sin captiverio que, aunque no hobiese infierno que amenazase, ni paraíso que convidase, ni mandamiento que constriñese, obraría por sólo el amor de Dios lo que obra." Ávila, Audi, filia, 497-98.

58 Cf. Constituciones de la Compañía de Jesús [134]: "La suma Sapiencia y Bondad de Dios nuestro Criador y Señor es la que ha de conservar y regir y llevar adelante en su santo servicio esta mínima Compañía de Jesú, como se dignó comenzarla, y de nuestra parte, más que ninguna esterior constitución, la interior ley de caridad y amor que el Spíritu Sancto escribe en los corazones ha de ayudar para ello." In Obras de San Ignacio de Loyola: Edición manual, ed. Ignacio Iparraguirre, S.J., Cándido de Dalmases, S.J., Manuel Ruiz Jurado, S.J., $5^{\text {th }}$ edition (Madrid: Biblioteca de Autores Cristianos, 1991) 494. 
the reader is counselled to practise renunciation of self so that God may act within:

When you understand this divine activity, you will understand a great part of Sacred Scripture, and you will enjoy great peace, rest and meekness of soul in walking continuously along this path that is so sure, namely: denying yourself in all things, and letting God act always. ${ }^{59}$

Here, again, we may note a parallel with the Exercises, in which indifference, and the self-abnegation it implies, is the disposition required for God's will to be communicated to the soul. ${ }^{60}$

These teachings on prayer naturally led the alumbrados to take an interest in the discernment of spirits. Jean Gerson's (1363-1429) treatise on the subject, De probatione spirituum (On the discernment of spirits), was translated into Spanish by one of the leading dexados, Antonio de Baeza ${ }^{61} \mathrm{It}$ is clear from the Inquisition's records that during the $15^{20}$ s the recogido friar Francisco de Ortiz (c.1492-c.1540) habitually used Gerson's rules to distinguish the promptings of the Lord from those of the devil. ${ }^{62}$ The Spanish Erasmians, too, were conscious of the importance of discernment, particularly after the appearance of Erasmus's paraphrase of Matthew's Gospel, which stressed the Christian's need to distinguish carefully, by means of the discretio spirituum, between the spirit of Christ and that of the world. ${ }^{63}$ The Paraphrasis in Evangelium Matthaei was published by Miguel de Eguía (1495-1544) in June 1525, just twelve months before Ignatius arrived in Alcalá and made his acquaintance. ${ }^{64}$

There is no evidence that these teachings and developments had a shaping influence on the Exercises. Nonetheless, there are clear parallels between the

59 "Entendiendo este obrar divino, entenderás mucha parte de la sagrada escriptura, y gozarás de gran paz, reposo y mansedumbre de tu ánima andando siempre por este camino tan verdadero, conviene a saber: deshazerte en todas las cosas, y que obre Dios siempre." Quoted in Asensio, "El erasmismo y las corrientes espirituales afines," 81-82. On the teachings of Bernabé de Palma see Andrés, Los recogidos, 176-92.

6o See Veale, Manifold Gifts, 117-18.

61 Hamilton, Heresy and Mysticism, 33.

62 Angela Selke, El Santo Oficio de la Inquisición: proceso de Fr. Francisco Ortiz (1529-1532) (Madrid: Guadarrama, 1969) 89n15. Later in his life (c.1541-45) Ortiz composed, with his brother Pedro, a series of annotations on the Election in the Exercises: their Tractatus de electione is edited in MHSI, Exerc. Spir., 627-45. On Ortiz's practice of recogimiento see Andrés, Los recogidos, ${ }^{68-75}$.

63 H. T. Levi, "Erasmus, the early Jesuits and the Classics," in Classical Influences on European Culture, AD 1500-1700, ed. R. R. Bolgar (Cambridge: Cambridge University Press, 1976) 223-38.

64 Bataillon, Érasme et l'Espagne, 1:175-76; 2:63, 406. 
confidence in divine guidance that they suppose and Ignatius's affirmation in the fifteenth annotation that to the soul seeking his will God communicates himself, embracing it in his love and praise, and disposing it (disponiéndole) in the way of serving him best [Sp.Ex. 15]. The Exercises, it is true, do not ascribe this divine action explicitly to the Holy Spirit, but implicit in them is a rich pneumatology, which modern commentators have sought to bring out. Few would now disagree with the statement of Harvey Egan that when the text is read in the context of Ignatius's own mystical life, "the importance of the Holy Spirit for the exercitant's consolation, discernment, election and experience of Christ becomes apparent."65

Cano's objections to this feature of the Spanish reform may be traced in his comments on Carranza's catechism, where two passages, in particular, caught his eye. The first, on the gift of counsel that the Holy Spirit confers, runs as follows:

To avoid error and to find assurance in the life we are living, which is full of so much danger and darkness, we need, instead of relying on our prudence, to consult God, so that he may enlighten us about what we should choose in all our present undertakings, and not only in those that are necessary, in order to direct our lives directly towards our salvation. ${ }^{66}$

The second passage concerns religious vows. No one, Carranza had written, should take a vow of perpetual chastity before reaching maturity, when he can evaluate his own resources, physical and spiritual. Having done so he may proceed, "to choose the state that God inspires." ${ }^{67}$ Here, there is an evident parallel

65 Harvey D. Egan, S.J., The Spiritual Exercises and the Ignatian Mystical Horizon (St. Louis: The Institute of Jesuit Sources, 1976), 122. See too Lera, "La contemplación para alcanzar amor," 163-90; Manuel Ruiz Jurado, S.J., "El Espíritu Santo en la espiritualidad ignaciana," Manresa 70 (1998): 217-30; Santiago Arzubialde, S.J., "Discernimiento - unción del Espíritu - y discretio: Presencia y actividad del Espíritu en los escritos de San Ignacio de Loyola," Manresa 70 (1998): 231-67; Rogelio García Mateo, S.J., "Dimensión pneumatológica de los Ejercicios Espirituales," in Ignacio de Loyola: Su espiritualidad y su mundo cultural, ed. Rogelio García Mateo, S.J. (Bilbao: Mensajero, 2000), 353-71.

66 "Es necesario, para no errar y para asegurarnos en la vida que vivimos, tan llena de peligros y de tantas tinieblas, no fiarnos de nuestra prudencia, sino consultar a Dios para que nos alumbre en lo que debemos de eligir en todos los negocios presentes, no solamente en los necesarios, para encaminar bien nuestra vida a salvarnos." Bartolomé Carranza de Miranda, Comentarios sobre el Catechismo christiano, ed. José Ignacio Tellechea Idígoras, 3 vols. (Madrid: Biblioteca de Autores Cristianos, 1972-1999), 1:365. On this passage see Cano, Qualificación [...] del Catechismo, 267.

67 "el estado que Dios [le] inspirare." Carranza, Comentarios sobre el Catechismo, 2:57-58: "Verdad es que vivir en perpetua continencia es cosa muy grave y muy rara, y que la alcanzan pocos, y por esto no se deben los hombres obligar por voto a este estado antes 
with the third time for making an election in the Exercises [Sp. Ex. 177]. Cano associates both passages with the practice of the alumbrados, who, misunderstanding the words of Paul, "the spiritual man judges all things" (1 Corinthians 2:15), held that the gifts of the Spirit emancipated them from the authority of the church and of learning:

These, consulting God by themselves in all matters human and divine, by means of the gift of counsel possessed by all the just, thought they were enlightened by the Holy Spirit in all their consultations, and thus, in practice and in their words, they ruled out the counsel of learned men, or at least considered it irrelevant. ${ }^{68}$

To rely, in such a way, on direct divine guidance from God was, in Cano's eyes, to expect an extraordinary grace, and he cited a passage in the New Testament to make his point. St. James, in his epistle, writes: "If any of you lacks wisdom, let him ask God [...] and it will be given him" (James 1:5). This, observes Cano, is not an invitation to pray for inspiration by the Holy Spirit: that would be to tempt God. Instead it means asking to be led to a teaching representative of the church, in order to receive instruction. ${ }^{69}$

De la Cruz is not as unfavorable as Cano to the desire for direct divine guidance. At one point in the Diálogo, Tomás recalls Christ's promise to be present wherever two or three are gathered in his name and reflects that if they are intent on his glory, he will not let them go astray. Antonio, however, qualifies his companions' words. One should also look for guidance, he says, to the teachings of the saints, who were led by the Spirit as well, and not neglect the natural gifts of one's mind: "Since the Lord gave man intelligence and memory, he doubtless wished him to use them in his actions and counsels, and not to expect to hear it all from his divine revelation." ${ }^{.70}$

que tengan edad para conocerse, en la cual con juicio y con maduro consejo puedan examinar sus fuerzas en el cuerpo y en el alma, y después con libertad y prudencia escoger el estado que Dios les inspirare, en el cual puedan mejor servir a Dios y salvarse." Cano cites other passages in the Catechism that make a similar point: Qualificación [...] del Catechismo, 267-68.

68 "Los quales en todas las cosas humanas e divinas consultando por sí mesmos a Dios por el don de consejo que todos los justos tienen, pensavan seer alunbrados del Espíritu Sancto en todas sus consultas, e assí en effecto e platica excluyan el consejo de los hombres doctos o, a lo menos, teníanlo por inpertinente." Cano, Qualificación [...] del Catechismo, 268.

69 Cano, Qualificación [...] del Catechismo, 354.

70 "Pues dio el Señor al hombre ingenio y memoria, quiso sin duda que usase de ello en sus obras y consejos, y no lo esperase oir todo de su divina revelación." De la Cruz, Diálogo sobre la necesidad, 239. 
De la Cruz, moreover, is skeptical about the extent to which anyone can be certain that the inspiration they have received does in fact come from God. Antonio asks: "Do all the perfect of the present day happen to possess that grace, freely given, that God bestowed on a few chosen ones in the early Church to discern spirits and distinguish good and evil?"71

His implication seems to be that the gift of discernment granted to the church in the past, and then only to a few, is an extraordinary grace, which one may not presume to possess. This is confirmed a short time later, when Antonio cites Augustine (354-430) to insist that the remarkable actions of the saints, which God inspired, are related for us to wonder at, not imitate, for we do not have the "divine instinct" that inspired them. ${ }^{72}$

Such comments place in their proper context some of the harshest criticisms directed against the Exercises by Cano and Pedroche. Cano describes the early Jesuits as "first cousins" (primos hermanos) of the illuminists, who were led into error by a false reading of John's promise that the anointing of Christ teaches all things (1 John 2:27):

The alumbrados and dexados [...], by devotion and contemplation and other things divine, bore as much fruit as these Fathers, and more [...], but gradually they came to think (following the false interpretation of what St. John the Apostle says, His anointing will teach you about all things) that they could not sin, and that they had only to do what occurred to their imagination, since they had offered themselves entirely to God. ${ }^{73}$

He singles out for special mention the image of a balance, which Ignatius uses twice (in the fifteenth annotation [Sp.Ex. 15] and in the rules for making an election [Sp. Ex. 179]) to convey the detachment required for God's will to be discerned:

71 ¿Por ventura tienen todos los perfectos de este tiempo aquella gracia gratis data que a algunos escogidos daba Dios en principio de la Iglesia para discernir los espíritus y distinguir el bueno del malo?" De la Cruz, Diálogo sobre la necesidad, 248.

72 De la Cruz, Diálogo sobre la necesidad, 248: "De las cuales dice San Agustín que son referidas para admiración y no para imitación, porque no tenemos el divino instinto que ellos tuvieron."

73 "Los Alumbrados y Dexados [...] por devoción y contemplación y otras cosas divinas hicieron tanto y más fruto que estos Padres [...], pero pasaron poco a poco (siguiendo la falsa interpretación de aquello del Apóstol San Juan, Unctio eius docebit vos de omnibus) a pensar que eran impecables, y que no habían de hacer sino lo que les venía a la imaginación, por haberse ofrecido todo a Dios." Cano, Censura, 12. 
They have a clause - not very wholesome - which says that although it is permissible to touch the heart [of the retreatant] in a fitting way, it will be better if his soul remains in suspense, to do whatever God may inspire in him. ${ }^{74}$

In his criticism of this feature, Pedroche goes even further than Cano. At the beginning of his report, he cites the anonymous text that prefaces the Exercises in the edition of 1548, where their origins are said to lie, not in books, but in the anointing of the Spirit, and the author's experience of prayer and helping souls. ${ }^{75}$ The admission that Ignatius, when composing them, depended more on inspiration than on learning is, for Pedroche, a link with the alumbrados:

From the inner experience of his heart, and the inner anointing of the Holy Spirit, rather than from books, the aforesaid Ignatius or Íñigo drew and composed these exercises and spiritual documents. This tastes, and not a little, of the spring of the dexados and alumbrados, who, leaving aside and making secondary what has been revealed in books, give and surrender themselves to what the spirit tells them, in their hearts, and hold it to be infallibly true that the spirit of God speaks to them always. ${ }^{76}$

His remarks call to mind the scene in the convent of San Esteban in Salamanca, recounted by Ignatius in his Reminiscences, when the Dominican sub-prior, Nicolás de Santo Tomás, reproached him for teaching his followers how to distinguish between virtue and vice: "You are not learned men [...] and you speak of virtues and vices; and of this no one can speak except in one of two ways: either through learning, or through the Holy Spirit. Not through learning: therefore, through the Holy Spirit."At the time, in the summer of 1527, controversy about the direction of the Spanish reform was intense. ${ }^{77}$

74 "Tienen una cláusula no muy sana que dice que quamvis licitum sit apto ad cor complecti, consultius erit quod anima eius maneat in aequilibrio, para hacer lo que Dios le inspirare." Cano, Censura, 20.

75 MHSI, Exerc. Spir., 79-81. The editors, in a note (79ni1), ascribe the text to Juan Alfonso de Polanco.

76 "Mas de la experiencia ynterior de su pecho, y de la ynterior uncion del Spiritu Sancto, que no de los libros, sacó y compuso el dicho Ignacio, ó Iñigo estos exercicios, y documentos espirituales. Lo qual sabe, y no poco a la fuente de los dexados y alumbrados, los quales dexado y pospuesto lo revelado en los libros, se remiten y entregan á lo que el espíritu les dice, dentro de su pecho, y tienen por cosa ynfalible que siempre les habla el spiritu de Dios." Pedroche, Censura, 505.

77 "Vosotros no sois letrados [...] y habláis de virtudes y de vicios; y desto ninguno puede hablar sino en una de dos maneras: o por letras, o por Espíritu Santo. No por letras; luego 
Elsewhere, Pedroche focuses on the second way of making an election in the third time, where Ignatius lays down the rule that "the love which moves me and makes me choose something has to descend from above" and that, before making a choice, the retreatant should have an "interior feeling or sense" that such is the case $[S p . E x .184] .{ }^{78}$ Pedroche objects to the implication that divine love may be experienced directly in a person's mind and will "that a man can feel within himself love infused from heaven, and that theological virtue which is charity, and not only that he can feel this, but that he can perceive it: in other words, frequently recognise it, by a spiritual and experimental knowledge, within himself." 79

He expresses reservations too about the first rule for almsgiving, which is phrased in similar terms [Sp.Ex. 338], ${ }^{80}$ and asks: what degree of knowledge is being implied here? If the knowledge Ignatius has in mind is conjectural and provisional, that is fine, but if, as seems evident, it is more certain than that, and of a demonstrative and experiential sort, then the rule is heretical. ${ }^{81}$ Clearly, he was scandalized by the confidence in divine guidance that the Exercises encourage and assume.

The opposition of some Spanish Dominicans to the Exercises during the last decade of Ignatius's life can help us to understand in more detail why the early Society was accused of being illuminist. Ignatius was never one of the alumbrados, but there are parallels between his spirituality and their teachings, particularly those of the recogidos. These parallels touch on elements of the Exercises connected with their "dynamic," a dynamic driven by the summons

por Espíritu Santo." Autobiografía [65], in Obras completas de San Ignacio, 129. See Bataillon, Érasme et l'Espagne, 1:231 (on the encounter in San Esteban) and 243-99 (on the Conference of Valladolid in 1527); José Martínez de la Escalera, S.J., "Salamanca," in García de Castro, ed., Diccionario de espiritualidad ignaciana, 2:1596-98.

78 "que aquel amor que me mueve y me hace eligir la tal cosa, descienda de arriba del amor de Dio." and "que sienta [...] primero en sí."

79 "Quod homo potest sentire in se amorem coelitus infusum, et caritatem virtutem illam theologicam, et non solum potest id sentire, sed potest id sentiscere, scilicet frequenter id cognoscere sensuali et experimentali cognitione, in se ipso." Pedroche, Censura, 517.

8o Sp.Ex. 338: "que aquel amor que me mueve y me haze dar la limosna, descienda de arriba, del amor de Dios nuestro Señor; de forma que sienta primero en mý que el amor más o menos, que tengo a tales personas, es por Dios, y que en la causa porque más las amo reluzca Dios."

81 Pedroche, Censura, $5^{22-23}$. 
of "the Creator and Lord," who disposes the soul towards the way that will best serve him $[S p . E x .15] .^{82}$ It remains to consider briefly a further issue: the impact of the Dominican attacks on how the Exercises were subsequently interpreted. This is a question that goes beyond the confines of the present study, but two observations may, perhaps, be made.

First, the situation up to 1560 . According to Iparraguirre, the impact made by Cano and Pedroche was minimal. Even in Salamanca and Toledo, where they were based, the Exercises continued to flourish, despite their views. ${ }^{83}$ This, however, is to forget that the two Dominicans, and those whose ideas they represented, were part of a more widespread reaction, in France and Italy as well as Spain, against the religious upheavals of the $15^{20}$. In France, where the forum of debate was Paris, traditional values were upheld by the Sorbonne. In Italy, the reaction was led by Cardinal Gian Pietro Carafa (1476-1559), and his Dominican associate, Michele Ghislieri (1504-72). As the mid-century drew near, the influence of the conservatives in Italy and Spain grew steadily, and it reached its strongest point in the late $1550 \mathrm{os}$. In Spain, their ascendancy coincided with the discovery of Protestant cells in Seville and Valladolid and the arrest of Carranza. In Italy, the turning point was the election of Carafa to the papacy in $1555 .{ }^{84}$ In both countries, the conservatives looked on the Jesuits with suspicion, and for similar reasons. ${ }^{85}$ The reservations voiced by Cano have much in common with those held by Carafa, and it is significant that after Carafa's election Cano intended to travel to Rome to present his treatise to the pope ${ }^{86}$ For both men, the crisis of the church, which the Jesuits reflected, was connected with the language of spirituality and pastoral theology. Each wished to fashion a theological idiom of pristine orthodoxy, and, with this end in mind, to eliminate from vernacular works of devotion terms, themes, and expressions that could be considered heterodox. Their quest led, in the late 1550s, to the draconian Index of Prohibited Books, which appeared in Italy and Spain. ${ }^{87}$

82 "disponiéndola por la vía que mejor podrá servirle adelante." The "dynamic" of the Exercises is a theme in Ivens, Understanding the Spiritual Exercises (see 567 for specific references). The use of the term is discussed in Veale, Manifold Gifts, $41-58$.

83 Iparraguirre, Práctica de los Ejercicios, 1:97-98, 126-27.

84 Bataillon, Érasme et l'Espagne, 1:743-49; 2:279-86; Diarmaid MacCulloch, Reformation: Europe's House Divided, 1490-17oo (London: Allen Lane, 2003), 276-80.

85 John W. O'Malley, S.J., The First Jesuits (Cambridge, MA: Harvard University Press, 1993), 292-96, 306-9.

86 Terence O'Reilly, "Melchor Cano and the Spirituality of St Ignatius Loyola," in Ignacio de Loyola y su tiempo, ed. Juan Plazaola, S.J. (Bilbao: Mensajero, 1992), 370, 379.

87 MacCulloch, Reformation, 299-300; Bataillon, Érasme et l'Espagne, 1:759-67; 2:290-302. 
Ignatius was keenly aware of these developments, and his concern to defend the Society against them may be seen in the Exercises. The rules with which the text concludes "To have the true sentiment which we ought to have in the church militant ${ }^{\prime 88}$ were intended, at least in part, to signal the allegiance of Ignatius and his companions at a decisive point, when the key issue in Catholic-Protestant debates was the locus and nature of the church [Sp.Ex. $35^{2-70}$. Exactly when they were composed is not clear, but it seems likely that they were influenced by the years Ignatius spent in Paris (1529-35), when the aspects of the church on which they dwell (the liturgy, the sacraments, popular devotions, authority and tradition) were being championed by the theologians of the Sorbonne. ${ }^{89}$ Furthermore, although the textual history of the Exercises before 1541 is uncertain, there is evidence that at some stage Ignatius removed expressions that might have been construed as illuminist, including several references to the Holy Spirit. ${ }^{90} \mathrm{He}$ appears to have judged that this was necessary to protect the Exercises against their foes, and his policy was vindicated in 1548 , when they were granted papal approbation.

Second, the situation up to 1600 . By the end of 1560 , both Cano and Carafa had died, but the agenda they had shaped continued to influence the church. In the latter part of the century, and in accord with the norms of the 1550s, vernacular works of devotion published in Spain usually observed a clear distinction between religious and lay spirituality. ${ }^{91}$ The expected outcome of the exercises they provided was not, normally, contemplation, but resolutions to practise virtues and good works in keeping with a person's calling. Far from celebrating consolation, they tended to underline instead that feelings of spiritual joy were secondary, and should be treated with detachment, while the experience of direct guidance by the Spirit, if it featured at all, was depicted as an extraordinary grace that one should not expect to receive. The situation eased slightly after the 1583 Index of Cardinal Gaspar de Quiroga (1512-94) and the publication of the writings of Teresa of Ávila in 1588, but in devotional

88 "Para el sentido verdadero que en la Iglesia militante debemos tener."

89 See the discussion in Jesús Corella, S.J., Sentir la Iglesia: Comentario a las reglas ignacianas para el sentido verdadero de la iglesia (Bilbao / Sal Terrae: Mensajero / Maliaño, 1995), 44-49, 107-8.

$90 \quad$ Leo Bakker, S.J., Freiheit und Erfahrung:Redaktionsgeschichtliche Untersuchungen uber die Unterscheidung der Geister bei Ignatius von Loyola (Würtzburg: Echter, 1970), 300-5; Egan, Spiritual Exercises, 120-21; José María Lera, S.J., "Espíritu Santo," in García de Castro, ed., Diccionario de espiritualidad ignaciana, 1:804.

91 Terence O'Reilly, "Meditation and Contemplation: Monastic Spirituality in Early Sixteenth-Century Spain," in Faith and Fanaticism: Religious Fervour in Early Modern Spain, ed. Lesley K. Twomey (Aldershot: Ashgate, 1997), 37-57. 
literature of a pastoral and catechetical kind a clear line between the ascetical and the mystical continued to be observed ${ }^{92}$ Meanwhile, in theological circles, there developed an intense debate about the nature and limits of "orthodox" language, notably among the Spanish Dominicans involved in the trial of Carranza, which lasted, first in Spain and then in Rome, until $1576 .{ }^{93}$

During the same period, the Society of Jesus was preoccupied with language too, in particular with how to define and use correctly the terminology of the Exercises that Ignatius had bequeathed. The directories that survive from the years 1560 to 1590 show a variety of interpretations of the work, some of them divergent, and it is clear that the bones of contention, on which views differed, included the issues that Cano and Pedroche had raised: the place, if any, of contemplation; the role of consolation; and the experience of direct divine guidance. ${ }^{94}$ Even more significantly, the terms and categories in which such matters were discussed were those that Cano and Pedroche had used, including a firm distinction between the ascetical and the mystical. This is evident in the approach to the Exercises adopted by Superior General Everard Mercurian (1514-80; in office $1573-80),{ }^{95}$ and in the controversies to which it gave rise. ${ }^{96}$ It is apparent also in the more moderate line taken by Jerónimo Nadal (150780), ${ }^{97}$ whose description of the Jesuit as contemplativus simul in actione joined together two concepts that Ignatius himself had never contrasted. ${ }^{98}$ In this respect, the criticisms of Cano and Pedroche may be said to have had a profound,

92 This was the view of Louis Cognet, who observed of devotional writers in Spain in the aftermath of the Index of 1559: "un même trait commun marque tous ces auteurs: une volontaire limitation au domaine moins périlleux de l'ascèse, avec de rares et discrêtes allusions aux problêmes contemplatifs. La situation se mettra longtemps à se défendre." La spiritualité moderne, vol. 1: L'essor: 1500-1650 (Paris: Aubier, 1966), 172.

93 See the introduction by Tellechea Idígoras to his edition of the Catechismo of Carranza, 1:38-45. The role played by Jesuits in the process of Carranza is considered in O'Malley, First Jesuits, 317-20.

94 Miguel Lop, S.J., "Directorios," in García de Castro, ed., Diccionario de espiritualidad ignaciana, 1:603-6; Javier Melloni, S.J., La mistagogía de los Ejercicios (Bilbao: Mensajero / Sal Terrae: Maliaño, 2001), 229-31; Alfredo Sampaio, S.J., Los tiempos de elección en los directorios de Ejercicios (Bilbao: Mensajero / Sal Terrae: Maliaño, 2004), especially 293-303.

$95 \quad D H C J, 2: 1611-12$.

96 Philip Endean, S.J., "The Original Line of Our Father Ignatius': Mercurian and the Spirituality of the Exercises," in McCoog, Mercurian Project, 35-48.

$97 \quad$ DHCJ, 3:2793.

98 Veale, Manifold Gifts, 107-8; Joseph F. Conwell, S.J., Walking in the Spirit: A Reflection on Jerónimo Nadal's "Contemplative likewise in Action" (St. Louis, MO: Institute of Jesuit Sources, 2003); Robert A. Maryks, “Jerónimo Nadal," in García de Castro, ed. Diccionario de espiritualidad ignaciana, 2:1318; Miguel Lop, S.J., “'Contemplativo en la acción' es quien halla a Dios en todas las cosas," Manresa 79 (2007): 339-56. 
if indirect, influence on the formation of a specifically Jesuit spiritual discourse, which was not fully attained until the completion in 1599 of the Official Directory, during the generalate of Claudio Acquaviva (1543-1615; in office $1581-1615) \cdot{ }^{99}$

$99 \quad D H C J, 2: 1614$. 